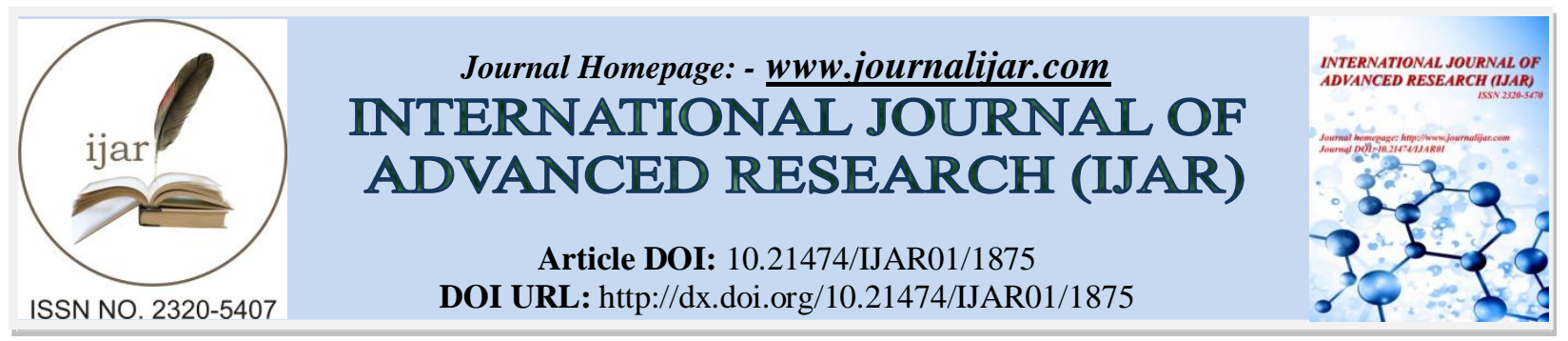

RESEARCH ARTICLE

\title{
MACRONUTRIENT STATUS AND THEIR SPATIAL VARIABILITY IN SOILS OF MELENG WATERSHED OF JORHAT DISTRICT, ASSAM - A GIS APPROACH.
}

\author{
Timothy Lalrinfela ${ }^{1 *}$, M.C. Talukdar ${ }^{1}$, B.K. Medhi ${ }^{1}$, R.K. Thakuria ${ }^{2}$.
}

1. Department of Soil Science, Assam Agricultural University, Jorhat 785013, India.

2. Department of Agronomy, Assam Agricultural University, Jorhat 785013, India.

\section{Manuscript Info}

Manuscript History

Received: 12 August 2016

Final Accepted: 23 September 2016

Published: October 2016

Key words:-

Spatial distribution, global positioning system (GPS), watershed, geographic

information system (GIS), correlation

\section{Abstract}

This paper determined dominant factors that affect stock prices in Rwanda. It specifically determined factors that affect stock prices in Rwanda and the direction of causality between stock prices and its determinants employing quarterly data spanning from 2011-2015. After identifying all the variables to be of the same order i.e. I(1), this study employed the Johnsen cointegration test to determine long run relationships and the Granger technique to determine the direction of causal relationship between stock prices and its factors in Rwanda.

Copy Right, IJAR, 2016,. All rights reserved.

The productivity of rice in India has to increase from present average value of 3.5 to $6.0 \mathrm{t} \mathrm{ha}^{-1}$ by the year 2025 , to meet the growing need of the population. Our aim of optimizing the utilization of land resources with intensification of agriculture had either resulted in faster depletion of nutrients or occasionally their accumulation. The indiscriminate use of fertilizers over a period of time has resulted in buildup of nutrient elements like phosphorus and deficiency of sulphur in many locations (Sharma, 2004). In order to tackle such problems, the concept of watershed based development in association with a spatial database regarding fertility status of soil has emerged as one of the potential approach to increase productivity and maintain sustainability of the soil in rainfed as well as irrigated areas. Application of fertilizers by the farmers in the field without prior knowledge of soil fertility status might result in adverse effect on soils as well as crops both in terms of nutrient deficiency and toxicity either by the inadequate or overuse of fertilizers.

The integration of remote sensing (RS) with geographic information system (GIS) and global positioning system (GPS) is helpful to monitor the changes of soil fertility components. With the increasing approach towards precision agriculture, the process of mapping, evaluation, monitoring and management of resources through RS and GIS has become efficient and inevitable platform. The application of these tools and techniques not only facilitates timely and repetitive analysis of all topographical features, but also assist in development of Decision Support System (DSS) to generate alternative scenario for optimal use of the natural resources in the long term. Keeping this in view, present study was taken up in Meleng wateshed of Jorhat district to study the spatial distribution of macronutrient status of the soils and their relationship with soil physical and chemical properties.

Meleng watershed falls under AS-2 UBVZ of Assam agro-ecological zones, which is located between $94^{\circ} 19^{\prime} 9.27^{\prime \prime}$ to $94^{\circ} 23^{\prime} 36.22^{\prime \prime} \mathrm{E}$ longitude and $26^{\circ} 42^{\prime} 2.64^{\prime \prime}$ to $26^{\circ} 48^{\prime} 11.69^{\prime \prime} \mathrm{N}$ latitude with an area of 900 ha. The average elevation is $89.67 \mathrm{~m}$ above mean sea level. The area experiences sub-tropical humid climate with a mean annual rainfall and temperature of $1972.3 \mathrm{~mm}$ and $26^{\circ} \mathrm{C}$, respectively. Soil moisture control section (SMCS) of the watershed falls under Aquic and Udic moisture regime with mean annual soil temperature (MAST) of Hyperthermic. 


\section{Materials and Methods:- \\ Collection of Soil Samples:-}

The digital satellite data of IRS 1C (LISS III) covering the watershed area on 1: 20000 scale was interpreted to delineate various land use and variation in surface features for sampling plans. Geo-referenced surface soil samples $(0-15 \mathrm{~cm})$ totaling 82 , representing different soils and land use in Meleng watershed were collected randomly using GPS (to mark the location of soil samples i.e. x,y coordinates) during the first week of March, 2013.

\section{Analysis of Samples:-}

The soil samples were air dried, ground and sieve through $2 \mathrm{~mm}$ sieve. Soil reaction was determined by potentiometric method (Jackson, 1973). Other soil analysis included determination of particle size analysis by international pipette method (Piper, 1966), cation exchange capacity (CEC) by centrifuge method (Jackson, 1973), organic carbon (OC) by wet oxidation method (Jackson, 1973), water holding capacity (WHC) and bulk density (BD) was measured by keen-rackzowski box method (Piper, 1966). Available nitrogen (N) was estimated by alkaline permanganate method of Subbiah and Asija (1956). Available phosphorus (P) was determined by Bray's I method (Bray and Kurtz, 1945), available potassium (K) was extracted by shaking the requisite amount of soil samples with $1 \mathrm{~N} \mathrm{NH}_{4} \mathrm{OAc}(\mathrm{pH}$ 7.0) solution for 5 minutes. The filtrate was used for determining available $\mathrm{K}$ with the help of flame photometer (Jackson, 1973) and available sulphur (S) was determined by turbidimetric method (Black, 1965).

\section{Generation of Maps:-}

The point locations of samples (i.e. latitude and longitude) were feed into the GIS environment to generate sampling site map. After analyzing the samples for various macronutrient and other important soil properties, the values were tagged with each geo-reference point. The points having the same value were grouped and classify them as a polygon and the maps for individual macronutrients and other important soil properties were digitized using Arc GIS. The maps thus generated for macronutrients were integrated in Arc GIS to generate macronutrient and other important soil properties maps.

\section{Results and Discussion:- Physico-chemical properties:- Soil texture:-}

Textural class of soils of Meleng watershed were mostly sandy loam, with few pockets of loamy and sandy clay loam texture. Surface soil samples were characterized by a sand content ranging from 54.84 to 77.12 per cent, silt content ranged from 8.28 to 27.28 per cent and clay content ranged from14.60 to 25.80 percent (Table 1). The dominance of sandy loam (nearly 92\%) was mainly attributed to the washing down of finer fractions (silt plus clay) from the surrounding hill slopes, which get deposited at the plains. Similar finding was reported by Rao et al. (2008).

\section{Soil reaction $(\mathrm{pH}):-$}

The $\mathrm{pH}$ of the studied soil samples varied from 4.6 to 7.3, which ranged from strongly acidic to neutral in reaction (Table 1). About 44.19 per cent soil samples had pH between 5.8 and 6.0. The soils are mostly acidic in reaction. This might be due to release of organic acids like $-\mathrm{COOH}$ and $-\mathrm{OH}$ groups due to decomposition of organic matter by soil microbes, which contributed to soil acidity. The finding is in conformity with the finding of Dolui et al. (2010).

\section{Organic carbon (OC):-}

The organic carbon content of the studied area ranged between 1.59 and $0.32 \%$, with an average value of $0.87 \%$ (Table 1). OC content in the range of 0.69 to $0.87 \%$ occupied the largest area with $53.64 \%$ of the total area. This indicated that the $\mathrm{OC}$ content was mostly in a medium to high range. This might be due to the subsequent decomposition of crop stubbles left in the soil after harvest and organic matter deposition from the surrounding hill slopes. The finding is in conformity with the finding of Deka (2005) and Rao et al (2008).

\section{Cation exchange capacity (CEC):-}

The cation exchange capacity of these soils varied from maximum value of 9.31 to a minimum value of 3.07 $\mathrm{cmol}\left(\mathrm{p}^{+}\right) \mathrm{kg}^{-1}$, with an average value of $7.13 \mathrm{cmol}\left(\mathrm{p}^{+}\right) \mathrm{kg}^{-1}$ (Table 1). The CEC was found to have a significant 
positive correlation with soil organic carbon and clay content. The finding is in conformity with the findings of Verma et al. (2010).

\section{Bulk density (BD):-}

The bulk density of these soils ranged from 1.21 to $1.64 \mathrm{Mg} \mathrm{m}^{-3}$ with an average value of $1.44 \mathrm{Mg} \mathrm{m}^{-3}$ (Table 1). There was a low standard deviation (0.07), which indicated that the BD was fairly well balanced at the study area. Also, the sand content was found to have a significant positive correlation with sand content. This is substantiated by the findings of Askin and Ozdemir (2003).

\section{Water holding capacity (WHC):-}

The water holding capacity of the soil in the watershed ranged between 23.89 to $42.16 \%$, with an average value of $34.22 \%$ (Table 1). Higher WHC was found in lowland areas, which might be due to dominance of finer soil particles at low lying areas. Similar finding was reported by Pachpor et al. (2012).

\section{Macronutrient status of soils:-}

\section{Available nitrogen:-}

The available $\mathrm{N}$ of the soils in the meleng watershed varied between 156.80 and $282.40 \mathrm{~kg} \mathrm{ha}^{-1}$ with an average value of $208.67 \mathrm{~kg} \mathrm{ha}^{-1}$ (Table 2). A low to medium range of available $\mathrm{N}$ was observed under high soil organic matter content. This might be due to slow mineralization process, which was mainly due to high clay content. Fine textured soils high in clay content were abundant in micropores in which organic matter can find protection from microbial decomposition (Deenik, 2006). The lowest available $\mathrm{N}$ was found in rice fallow soils. This might be due to anaerobic saturated condition leading to immobilization and progressive reduction in soil labile $\mathrm{N}$.

\section{Available Phosphorus:-}

The available $\mathrm{P}$ in these soils ranged between 10.56 and $37.86 \mathrm{~kg} \mathrm{ha}^{-1}$, with an average value of $24 \mathrm{~kg} \mathrm{ha}^{-1}$ (Table 2). About $75 \%$ of samples tested were medium and $24 \%$ had low P status. Medium content of P in majority of soils may be attributed to the $\mathrm{pH}$ condition that had influenced the conversion of Al-P and Fe-P towards available $\mathrm{P}$. Maximum available $\mathrm{P}$ was also found in a $\mathrm{pH}$ ranged between 5.5 and 6.5. $\mathrm{P}$ availability in most soils were at a maximum near pH 6.5 (Havlin et al, 2007). P adsorption capacity was found to be lowest in sandy loam texture soils (Chand and Tomar, 2009).

\section{Available Potassium:-}

The available $\mathrm{K}$ content of the study area ranged between 54.70 and $342.72 \mathrm{~kg} \mathrm{ha}^{-1}$, with an average value of 179.31 $\mathrm{kg} \mathrm{ha}^{-1}$ (Table 2). Wide range of available $\mathrm{K}$ was observed from low to high range. Nearly $76 \%$ of the samples tested were medium, which were mostly found at tea plantation and rice vegetable land use. This might be due to more humification, which release labile $\mathrm{K}$ from organic residues as well as upward translocation with capillary rise of ground water. A positive correlation of available $\mathrm{K}$ with soil organic carbon substantiate the finding $\left(\mathrm{r}=0.571^{* *}\right)$. These results are in accordance with the findings of Podder (1997).

\section{Available Sulphur:-}

The available S content of the watershed ranged from 26 to $87.50 \mathrm{~kg} \mathrm{ha}^{-1}$, with an average value of $50.59 \mathrm{~kg} \mathrm{ha}^{-1}$ (Table 2). Nearly, 72 and $27 \%$ samples tested medium and high in available S, respectively. This might be due to high organic carbon content at the study area, which is supported by a significant positive correlation of available $\mathrm{S}$ with soil organic carbon $\left(\mathrm{r}=0.426^{* *}\right)$. Similar observation was reported by Borkotoki and Das (2008).

\section{Spatial Distribution of Soil fertility parameters in Soils of meleng watershed:-} Organic carbon:-

The overall distribution of organic carbon in meleng watershed area was low to high. About 706.80 ha soils (78.53\%) of the area contained organic matter between 0.69 to 1.6 per cent., while only 193.20 ha of the study area (21.47\%) organic carbon content were low (Fig. 1, Table 3).

\section{Soil reaction:-}

The overall soil reaction of the watershed was strongly acidic to neutral. Out of the total geographical area (900 ha) of the watershed, 511.40 ha soils $(57.12 \%)$ were found to be in moderately and slightly acidic within a pH range of 5.8 to 6.3 , while the least reported to be in strongly acidic (4.6 to 5.48) condition (8.20\%) with an area of 8.20 ha. (Fig. 2, Table 3). 


\section{Available Nitrogen:-}

Available nitrogen content of the watershed was found to be low. The available soil nitrogen map revealed that majority of the meleng watershed area 792.46 ha $(88.05 \%)$ contained available nitrogen below $218.49 \mathrm{~kg} \mathrm{ha}^{-1}$. Only about 107.54 ha $(11.95 \%)$ of the area were found have available nitrogen content above $218.49 \mathrm{~kg} \mathrm{ha}^{-1}$ (Fig. 3, Table $4)$.

\section{Available Phosphorus:-}

The available $\mathrm{P}_{2} \mathrm{O}_{5}$ content of the watershed was in low and medium status. The map showed that maximum $\mathrm{P}_{2} \mathrm{O}_{5}$ availability was found in the range of 22.66 to $29.09 \mathrm{~kg} \mathrm{ha}^{-1}$ with area coverage of 604.79 ha $(67.20 \%)$. While 222.68 ha of the study area (24.74\%) were found to have low phosphorus availability (Fig. 4, Table 4).

\section{Available potassium:-}

The available potash content of the watershed area was found to be mostly medium in status. In major portion of the study area (94.94\%) available potash content varied between 54.70 to $276.44 \mathrm{~kg} \mathrm{ha}^{-1}$. Only about 45.23 ha soils $(5.03 \%)$ area represented potash content above $276.44 \mathrm{~kg} \mathrm{ha}^{-1}$ (Fig. 5, Table 5).

\section{Available Sulphur:-}

The available sulphur content of the watershed was in medium and high status. The map showed that available sulphur content between 26.00 to $44.13 \mathrm{~kg} \mathrm{ha}^{-1}$ has the largest area coverage with 364.06 ha (40.45\%). The highest content of available sulphur 60.70 to $87.50 \mathrm{~kg} \mathrm{ha}^{-1}$ covered an area of $89.65 \mathrm{ha}(9.96 \%)$ (Fig. 6, Table 5).

\section{Relationship between Soil Properties and Available Nutrients:-}

The available $\mathrm{N}$ was found to have a significant positive correlation with $\mathrm{OC}\left(\mathrm{r}=0.644^{* *}\right)$, which indicated that soil organic matter was the contributing factor for available N. Similar finding was reported by Deka (2005). However, low available $\mathrm{N}$ was observed under high $\mathrm{OC}$ content. This might be due to slow mineralization process, which was mainly due to high clay content. Similar finding was reported by Deenik (2006). The available P was negatively and significantly correlated with $\mathrm{pH}(\mathrm{r}=-.361 * *)$ (Table 6) which indicated that the acidic condition of the soil have negative influence on the conversion of Al-P and Fe-P towards available $\mathrm{P}$, which is in accordance with the finding of Deka (1986). Due to presence of appreciable amount of negative sites at the exchange sites of clay and SOC higher values of available $\mathrm{K}$ was observed resulting to a positive correlation of potassium with clay ( $\left.\mathrm{r}=0.341^{* *}\right)$ and SOC $\left(\mathrm{r}=0.356^{* *}\right)$. Available $\mathrm{S}$ was found to have a significant positive correlation with SOC $\left(\mathrm{r}=0.426^{* *}\right)$ and clay $(\mathrm{r}=0.154)$ (Table 6), which confirms the observation reported by Borkotoki and Das (2008).

Table 1. Physico-chemical properties of soils of Meleng Watershed

\begin{tabular}{|l|l|l|l|l|l|}
\hline Soil properties & Minimum & Maximum & Mean & SD & CV (\%) \\
\hline pH $(1: 2$, Soil: water) & 4.6 & 7.3 & 6.11 & 0.46 & 7.5 \\
\hline OC $(\%)$ & 0.32 & 1.59 & 0.87 & 0.32 & 36.48 \\
\hline Sand (\%) & 54.84 & 77.12 & 65.34 & 4.96 & 7.59 \\
\hline Silt $(\%)$ & 8.28 & 27.28 & 17.25 & 4.78 & 27.76 \\
\hline Clay $(\%)$ & 14.60 & 25.80 & 17.56 & 1.79 & 10.21 \\
\hline CEC $\left[\mathrm{cmol}^{+}\left(\mathrm{p}^{+}\right) \mathrm{kg}^{-1}\right]$ & 3.07 & 9.31 & 7.13 & 1.57 & 22.07 \\
\hline BD Mg m & 1.21 & 3.07 & 1.44 & 0.07 & 5.24 \\
\hline WHC $(\%)$ & 23.89 & 42.16 & 34.22 & 4.44 & 12.97 \\
\hline
\end{tabular}

Table 2. Macronutrient status of soils $\left(\mathrm{kg} \mathrm{ha}^{-1}\right)$ of Meleng Watershed

\begin{tabular}{|c|c|c|c|c|c|}
\hline Nutrients & Minimum & Maximum & Mean & SD & CV $(\%)$ \\
\hline $\mathrm{N}$ & 157.40 & 282.40 & 208.67 & 28.88 & 14.09 \\
\hline $\mathrm{P}$ & 10.56 & 37.86 & 23.99 & 6.24 & 26 \\
\hline $\mathrm{K}$ & 54.70 & 342.72 & 179.31 & 65.83 & 36.71 \\
\hline $\mathrm{S}$ & 26 & 87.50 & 50.59 & 15.88 & 31.38 \\
\hline
\end{tabular}


Table 3:- Percentage of area falling in different ranges of $\mathrm{pH}$ and OC.

\begin{tabular}{|l|l|l|l|l|l|l|l|l|l|}
\hline \multicolumn{9}{|c|}{$\mathrm{pH}$} & \multicolumn{4}{c|}{ OC } \\
\hline Range & $4.6-5.4$ & $5.5-5.8$ & $5.9-6$ & $6.1-6.3$ & $6.4-7.2$ & $\begin{array}{l}0.32- \\
0.68\end{array}$ & $\begin{array}{l}0.69- \\
0.86\end{array}$ & $\begin{array}{l}0.87- \\
1.10\end{array}$ & $\begin{array}{l}1.20- \\
1.60\end{array}$ \\
\hline Area (ha) & 73.8 & 227.40 & 397.70 & 113.70 & 87.40 & 193.20 & 482.80 & 134.70 & 89.30 \\
\hline Percent (\%) & 8.2 & 25.27 & 44.19 & 12.63 & 9.71 & 21.47 & 53.64 & 14.97 & 9.92 \\
\hline
\end{tabular}

Table 4:- Percentage of area falling in different ranges of available $\mathrm{N}$ and $\mathrm{P}\left(\mathrm{P}_{2} \mathrm{O}_{5}\right)$

\begin{tabular}{|l|l|l|l|l|l|l|l|l|}
\hline \multicolumn{4}{|c|}{ Available N } & \multicolumn{5}{c|}{ Available $\mathrm{P}_{2} \mathrm{O}_{5}$} \\
\hline Range & $156.80-$ & $201.33-$ & $218.49-$ & $2.6-$ & $18.34-$ & $22.67-$ & $25.68-$ & $29.10-$ \\
& 201.33 & 218.49 & 281.04 & 18.33 & 22.66 & 25.67 & 29.09 & 37.85 \\
\hline Area (ha) & 458.09 & 334.37 & 107.54 & 80.05 & 142.63 & 272.94 & 331.85 & 72.55 \\
\hline Percent (\%) & 50.89 & 37.15 & 11.95 & 8.89 & 15.85 & 30.33 & 36.87 & 8.06 \\
\hline
\end{tabular}

Table 5:- Percentage of area falling in different ranges of available $\mathrm{K}\left(\mathrm{K}_{2} \mathrm{O}\right)$ and $\mathrm{S}$.

\begin{tabular}{|l|l|l|l|l|l|l|l|l|l|}
\hline \multicolumn{9}{|c|}{ Available $\mathrm{K}_{2} \mathrm{O}$} & \multicolumn{4}{c|}{ Available S } \\
\hline Range & $9.95-$ & $151.94-$ & $186.24-$ & $221.20-$ & $276.45-$ & $26.01-$ & $44.13-$ & $52.16-$ & $60.70-$ \\
& 151.93 & 186.23 & 221.19 & 276.44 & 430.01 & 44.13 & 52.16 & 60.70 & 70.35 \\
\hline Area (Ha) & 175.23 & 221.12 & 358.21 & 99.86 & 45.23 & 364.06 & 277.05 & 169.32 & 89.65 \\
\hline Percent (\%) & 19.47 & 24.57 & 39.80 & 11.09 & 5.03 & 40.45 & 30.78 & 18.81 & 9.96 \\
\hline
\end{tabular}

Table 6:- Correlation between macronutrients and chemical properties of the soil.

\begin{tabular}{|c|c|c|c|c|}
\hline Nutrients & pH & OC & Clay & CEC \\
\hline $\mathrm{N}$ & $-.262^{*}$ & $.644^{* *}$ & .179 & $.307^{*}$ \\
\hline $\mathrm{P}$ & $-.361^{* *}$ & $.290^{* *}$ & .216 & .178 \\
\hline $\mathrm{K}$ & $-.266^{*}$ & $.356^{* *}$ & $.341^{* *}$ & .098 \\
\hline $\mathrm{S}$ & $-.441^{* *}$ & $.426^{* *}$ & .154 & $.285^{* *}$ \\
\hline
\end{tabular}

* Significant at $5 \%$ level

** Significant at $1 \%$ level

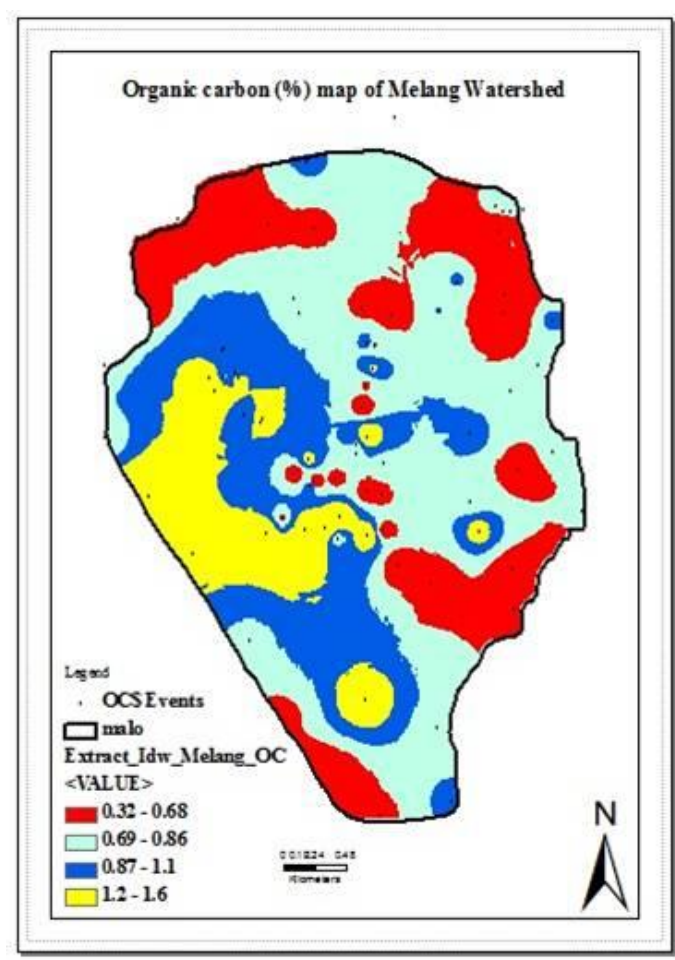

Fig. 1. Organic Carbon status in surface soils.

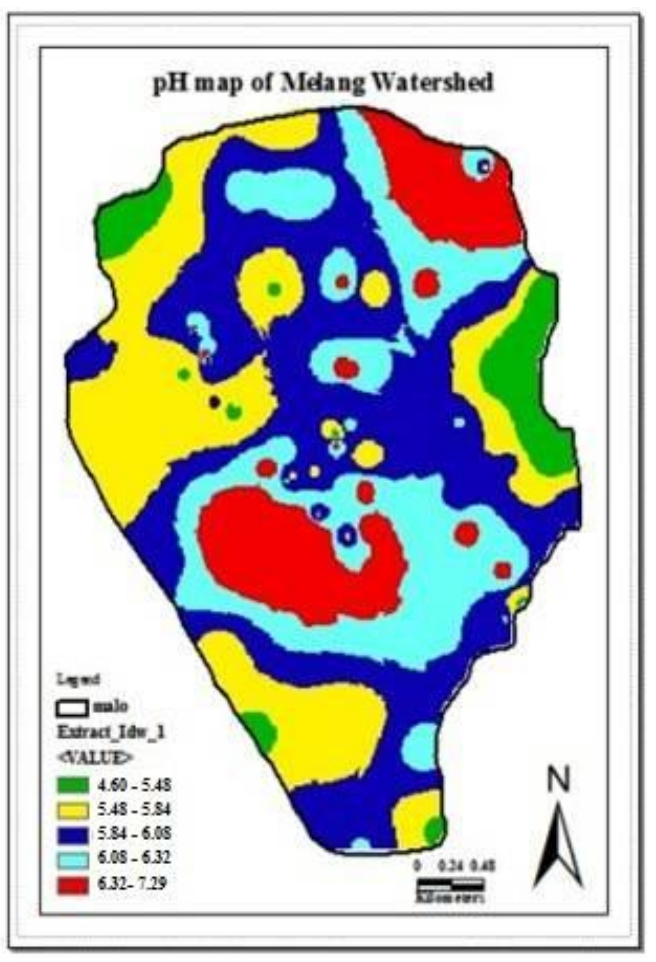

Fig. 2. Soil reaction in surface soils 


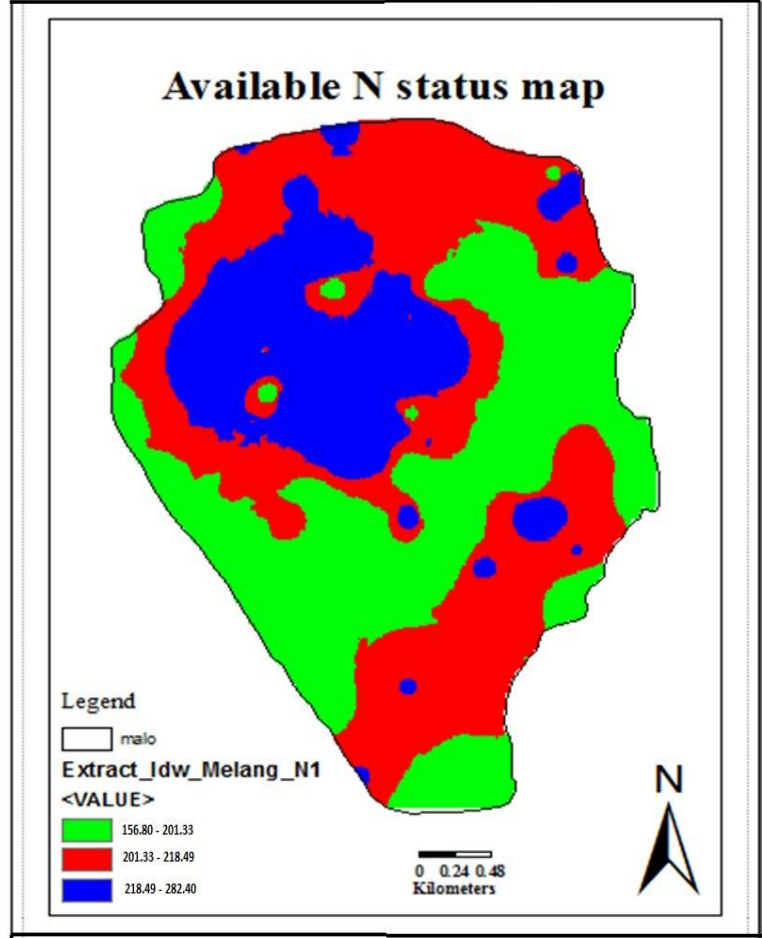

Fig. 3. Available $\mathrm{N}$ status in surface soils.

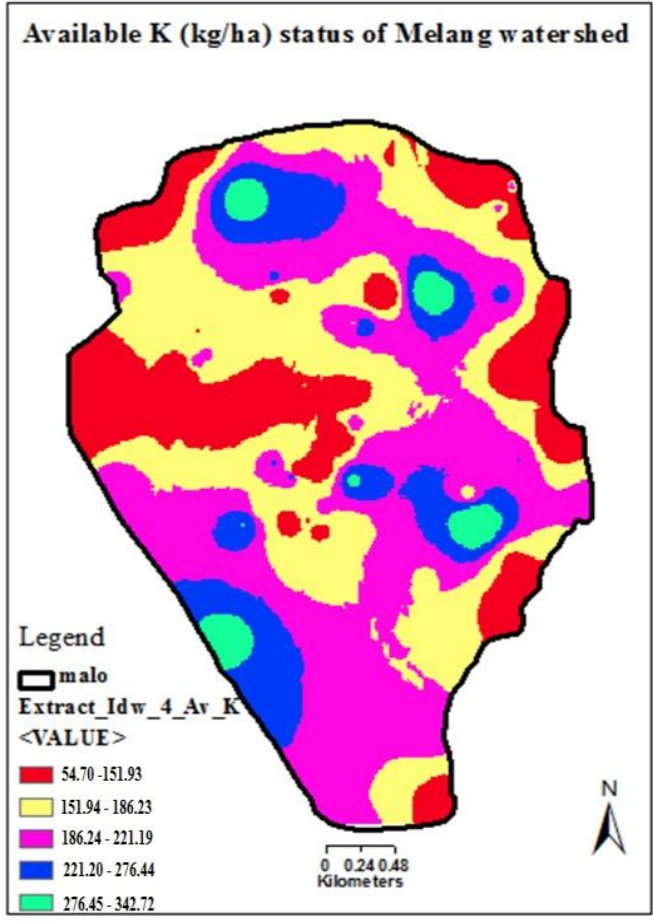

Fig. 5. Available K status in surface soils.

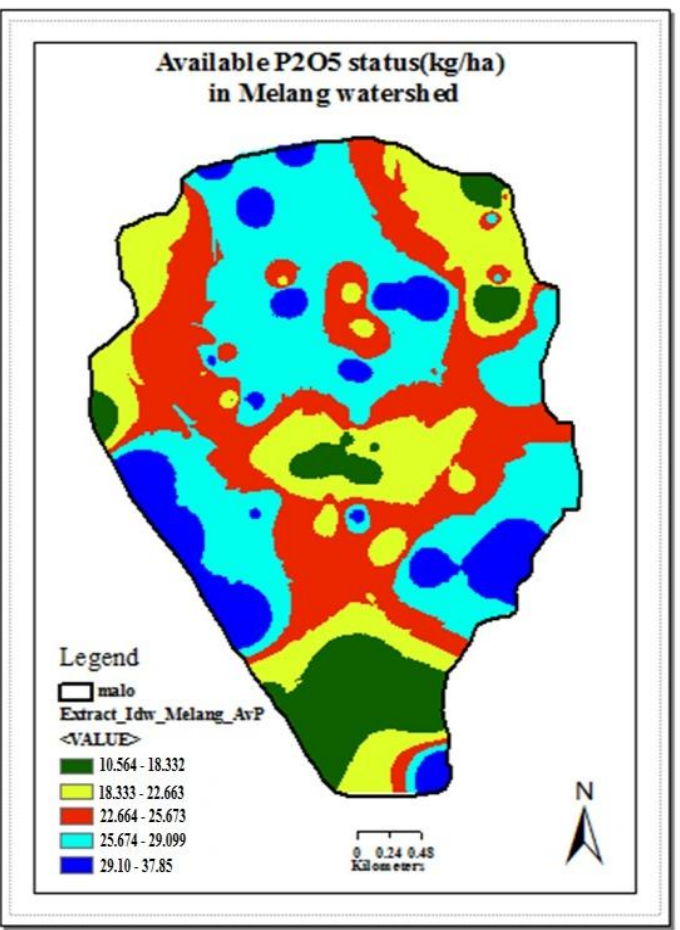

Fig. 4. Available $P$ status in surface soils.

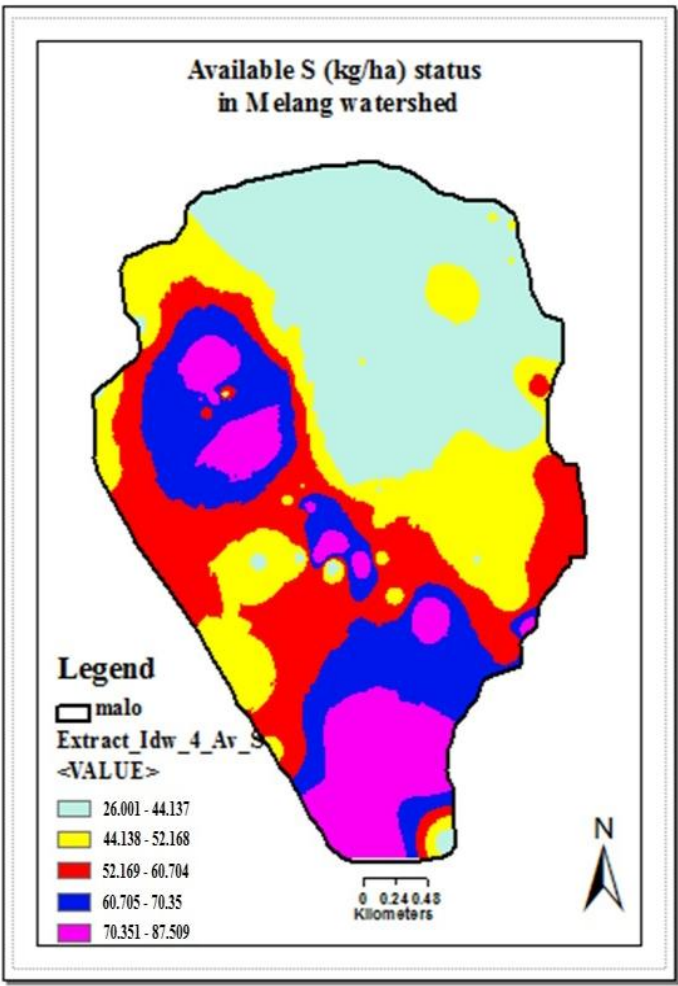

Fig.6. Available $\mathrm{S}$ status in surface soils.

\section{Conclusion:-}

The soil reaction varied from slightly acidic to moderately acidic (4.6 to 7.3) in reaction. The organic carbon content was high (0.32-1.59\%) due to retention of organic matter containing runoff and addition of large amount crop 
residues. The available $\mathrm{N}$ and $\mathrm{P}$ content was mostly low to medium due to crop removal and low mineralization process, therefore supplemental application of $\mathrm{N}$ and $\mathrm{P}$ fertilizers is the need of the hour. The available $\mathrm{K}$ and $\mathrm{S}$ varied widely from low to high. The effect of leaching, K fixation and organic matter decomposition had an immense effect on the availability of potassium and sulphur.

\section{References:-}

1. Askin, T. and Ozdemir, N. (2003). Soil bulk density as related to soil particle size distribution and organic matter content. Karadeniz Technical University, Faculty of Agriculture, Department of Soil Science, 52200, Ordul, Turkey;

2. Bhattacharyya, R.; Prakash, V.; Kundu, S.; Ghosh, B.N. and Gupta, H.S. (2008). Potassium availability as influenced by farmyard manure application under continuous soyabean-wheat cropping in a Typic haplaquept. J. Indian Soc. Soil Sci. 56 (2): 182-185.

3. Black, C.A. (1965). Method of soil analysis. Part II. American society of agronomy, Madison, Wisconsin,USA.

4. Borkotoki, B. and Das, K.N. (2008). Forms of sulphur and their relationship with soil properties in Entisols, Inceptisols and Alfisols of Assam. J. Indian Soc. Soil Sci. 56 : 186- 191.

5. Bray, R.H. and Kurtz, L.T. (1945). Determination of total organic and available forms of phosphorus in soils. Soil Sci. 59 : 39-46.Deenik, J. (2006). Nitrogern mineralization potential in important agricultural soils of Hawaii. Soil and Crop Management 15, Cooperative extension service, University of Hawaii at Manoa.

6. Chand, K. and Tomar, N.K. (2009). Phosohate adsorption behavior of the soils of Northwest India. J. Indian Soc. Soil Sci. 57 (3): 291-299.

7. Deka, C. (1986). Kinetics of P fixation and release in major soil order of Assam. M.Sc. (Ag.) Thesis, Assam Agricultural University (AAU), Jorhat.

8. Deka, B. (2005). Soil variability, erodibility and productivity potential of a transect in Brahmaputra valley using Remote sensing and GIS techniques. Ph.D (Agri.) Thesis, Assam Agric. Univ., Jorhat, Assam.

9. Dolui, A.K.; Kar, S. and Ghosal, M. (2010). Characterization and lime requirement estimation of acid soils of Nagaland. J. Indian Soc. Soil Sci. 58 (2): 147-153.

10. Havlin, J.L.; Beaton, J.D.; Tisdale, S.L. and Nelson, W.L. (2007). Soil fertility and fertilizers. Seventh edition, PHI Learning (India) Pvt. Ltd.

11. Jackson, M.L. (1973). Soil chemical analysis. Prentice Hall of India Pvt. Ltd., New Delhi.

12. Pachpor, S.D.; Nagaraju, M.S.S.; Srivastava, R.; Barthwal, A.K.; Nasre, R.A. and Mohekar, D. (2012). Characterization and evaluation of land resources for management of Savli micro-watershed in Wardha district of Marastra using geospatial technologies. Agropedology. 22 (1): 8-17.

13. Piper, C.S. (1966). Soil and plant analysis. University of Adelaide, Australia.

14. Rao, A.P.V.P.; Naidu, M.V.S.; Ramavatharam, N. and Rao, G.M. (2008). Characterization, classification and evaluation of soils on different landforms in Ramachandrapuram Mandal of Chitoor district in Andhra Pradesh for sustainable land use planning. J. Indian Soc. Soil Sci. 56 (1): 23-33.

15. Subbiah, B.V. and Asija, G.L. (1956).A rapid procedure for determination of available nitrogen in soils. Current science. 25: 259-260.

16. Sharma, P.K. (2004). Emerging technologies of remote sensing and GIS for development of spatial data infrastructure. J. Indian Soc. Soil Sci. 52 : 384-406.

17. Verma, G.; Mathura, A.K.; Bhandari, S.C. and Kanthaliya, P.C. (2010). Longterm effect of INM on properties of a typic haplustept under maize-wheat cropping system. J. Indian Soc. Soil Sci. 58 (3): 299-302. 